\title{
Ciliary Neurotrophic Factor
}

\author{
M. Sendtner, ${ }^{*}$ P. Carroll, B. Holtmann, R. A. Hughes, and H. Thoenen \\ Department of Neurochemistry, Max-Planck-Institute for Psychiatry, D-82152 Martinsried, Germany
}

\section{SUMMARY}

Ciliary neurotrophic factor (CNTF) was first identified and partially purified from embryonic chick eye tissues. Subsequently, it was shown that CNTF is also present in large amounts in sciatic nerves of adult rats and rabbits, which led to its final purification and cloning. CNTF is not secreted by the classical secretory pathway involving the endoplasmatic reticulum and Golgi complex, but can be detected in high quantities within the cytoplasm of myelinating Schwann cells and astrocytes using immunohistochemistry. CNTF supports survival and/or differentiation of a variety of neuronal cell types including sensory, sympathetic, and motoneurons. Also, nonneuronal cells, such as oligodendrocytes, microglial cells, liver cells, and skeletal muscle cells, respond to exogenously administered CNTF, both in vitro and in vivo. During development, expression of CNTF is very low, if indeed it is expressed at all, and the phenotype of mice lacking endogenous CNTF after inactivation of the CNTF gene by homologous recombination suggests that CNTF does not play a crucial role for responsive cells during embryonic development. However, motoneurons are lost postnatally in mice lacking endogenous CNTF, suggesting that CNTF acts physiologically on the maintenance of these cells. The ability of exogenous CNTF to protect against motoneuron loss following lesion or in other animal models indicates that CNTF might be useful in the treatment of human motoneuron disorders, provided appropriate means of administration can be found. (c) 1994 John Wiley \& Sons. Inc.

Reywords: ciliary neuron, ciliary neurotrophic factor, motoneuron, nonneuronal cells, homologous recombination

\section{CILIARY NEURONS: SPECIFIC PROPERTIES OF THE CELL TYPE USED FOR THE IDENTIFICATION OF CNTF}

In the chick and other avian species, the ciliary ganglion is a distinct, well-defined structure within the orbita. In contrast, in the rat, this ganglion is hardly recognizable, as most ciliary neurons are located in several dispersed groups in the retrobulbar space. Two populations of cholinergic neurons can be distinguished within the avian ciliary ganglion: A population of larger neurons (ciliary neurons) innervates the constrictor muscle fibers of the iris and the ciliary body. The smaller chorioid neurons innervate smooth muscle cells, mostly associated

Received April 27, 1994: accepted May 18. 1994

Journal of Neurobiology, Vol. 25, No. 11, pp. 1436-1.453 (1994)

(C) 1994 John Wiley \& Sons, Inc.

CCC 0022-3034/947111436-18

* To whom correspondence should be addressed. with blood vessèls within the chorioid layer (Marwitt et al., 1971). The myoepithelial cells forming the striated constrictor muscle fibers of the iris are derived from the ectoderm, and the striated ciliary muscle originates from mesoderm (Pilar et al., 1980), similar to the myoblasts forming the skeletal muscle. Ciliary neurons can be easily isolated and purified, and have therefore been widely used for studying the mechanisms involved in the formation of neuromuscular synapses and trophic interactions between muscle cells and innervating neurons (Betz, 1976; Hooisma et al., 1975; Wessells et al.. 1976; Helfand et al., 1976; Bader et al., 1982; Nishi and Berg, 1977, 1979).

In contrast to spinal motoneurons, which originate from and do not migrate outside the neural tube, ciliary neurons are derived from the mesencephalic neural crest (Le Douarin and Teillet, 1974: Landmesser and Pilar, 1974). In the chick embryo, ciliary neurons are born relatively early, the proliferative phase being completed by embryonic day 5 (E5) (Landmesser and Pilar, 1974). Most axons of 
both neuronal populations have reached their target cells by E6. At this time, the migration of myoblasts into the target area is still not complete ( summarized by Manthorpe and Varon, 1985). Between E8 and E12, about 50\% of the neurons within the ciliary ganglion degenerate. Removal of the eye before the period of cell death results in loss of more than $90 \%$ of the ciliary ganglionic neurons (Landmesser and Pilar, 1974). and transplantation of an additional eye, resulting in an increased target field, reduces cell death (Narayanan and Narayanan, 1978). An elegant study by Pilar et al. (1980) also demonstrated that interruption of one of the three nerve branches from the ciliary ganglion to the eye results in increased survival of neurons projecting within the remaining two nerve branches. Taken together, these results suggest that the eye is a source of survival factors for ciliary neurons, and these factors are available in limiting quantities, not sufficient to permit the survival of all the innervating ciliary neurons.

In the ciliary ganglion, not all neurons normally eliminated during development show the morphological signs of apoptosis. At the EM level, dying neurons show dilation of the rough endoplasmatic reticulum, whereas condensation or clumping of the chromatin-typical manifestations of initial stages of apoptosis-are not seen until late stages when changes in the cytoplasm are already extensive. In contrast, cells deprived of their target prior to the period of naturally occuring cell death show condensation of the nuclear ehromatin, as typically observed in apoptotic cell death (Pilar and Landmesser, 1976). Similar observations have been reported during the period of cell death of spinal preganglionic visceromotoric neurons and lumbar motor neurons after target removal (O'Connor and Wyttenbach, 1974).

Although nerve growth factor (NGF) has been shown to initiate short-term fiber outgrowth in cultured ciliary neurons (Collins, 1984), there is no evidence thus far that any of the neurotrophins support the survival of embryonic chick ciliary neurons in culture. Moreover, expression of trkA mRNA from an expression vector microinjected into cultured chick ciliary neurons does not lead to NGF responsiveness (Allsopp et al., 1993a). It has to be concluded from this result that the ciliary neurons lack the signalling machinery used by other neurons, including motoneurons, to transduce the survival signals of neurotrophins. Furthermore, bcl- 2 does not inhibit cell death of ciliary neurons, in contrast to results obtained with the neurotrophin-responsive trigeminal neurons (All- sopp et al., 1993b). In summary, these data indicate that ciliary neurons differ from neurotrophinresponsive neurons in many respects, including the intracellular pathways leading to the prevention of neuronal death.

\section{PURIFICATION AND CLONING OF CNTF: STRUCTURE AND PROPERTIES OF CNTF PROTEIN}

The isolation and culture of ciliary neurons from chick embryos (Helfand et al., 1976; Nishi and Berg, 1977: Adler et al., 1979; Hooisma et al., 1975) served as a basis for the development of a bioassay for the screening and purification of survival factors for these neurons. Ciliary neurons were found to survive when co-cultured with chick skeletal muscle cells (Nishi and Berg, 1977), rat eye tissue (Ebendal et al.. 1980), and sciatic nerve fragments (Richardson and Ebendal. 1982), and efforts were made to purify the agents responsible for these effects. A systematic analysis by Adler et al. (1979) showed that eye tissue, in particular the iris, ciliary body, and chorioid layer, was the richest source of a putative survival factor for ciliary neurons. In fact, these early studies revealed that the amounts of ciliary neuronal survival activity in the eye were so high that they were difficult to reconcile with the idea that the factor(s) responsible would be available only in limiting amounts. It was shown that the putative survival factor, which at that stage had been named ciliary neuronotrophic factor, differed from NGF, in that CNTF was an acidic protein with an estimated molecular mass of $20-24 \mathrm{kD}$. However, experiments with partially purified CNTF suggested that it did promote the survival of neurons known to depend on NGF, for example, sympathetic and sensory neurons from E10 (but not E8) chick embryos (Barbin et al., 1984. Manthorpe et al.. 1986).

Nishi and Berg ( 1981 ) found two components in chick eye tissue. one with a molecular weight similar to that proposed for CNTF (20kD) which they named growth promoting activity (GPA) and another factor which stimulated choline acetyltransferase activity without affecting neuronal survival, named ChAT-stimulating activity (CSA).

Sources other than the eye were also used for purification of ciliary neuronal survival factors, such as embryonic chick heart for a component with an estimated molecular mass of $40 \mathrm{kD}$ (Ebendahl et al., 1979) or ox heart for purification of a factor that later proved to be acidic fibroblast 
growth factor (FGF-1) (Watters and Hendry, 1987). Other factors supporting chick ciliary neuron survival were also partially purified from pig lung (Wallace and Johnson, 1987), rat skeletal muscle (Hill and Bennett, 1983), and other tissues from chick and rat ( for review, see Manthorpe and Varon 1986). McManaman and colleagues (1988) purified a factor from tat skeletal muscle named cholinergic differentiation factor (CDF) with properties very similar to rat CNTF (McManaman et al., 1990). The question whether CDF is identical to CNTF is as yet unresolved.

A method for partial purification of CNTF from chick eye was published by Barbin et al. (1984), and a subsequent study showed that this factor was very similar to a ciliary survival factor present in high amounts in adult rat sciatic nerve (Manthorpe et al., 1986). In these two reports, CNTF was enriched between 400 - and 800 -fold. However, the degree of purification from adult rat sciatic nerve necessary to obtain material suitable for partial protein sequencing ranged between 10,000 and 25,000 for rat CNTF (M. Sendtner, unpublished results) and 35,000 for rabbit CNTF (Lin et al., 1990).

Based on partial amino acid sequence data, the cDNAs for rabbit and rat CNTF were cloned (Lin et al., 1989; Stöckli et al., 1989). Subsequently, rat. mouse, and human genomic clones were identified and analyzed: The CNTF gene was mapped to mouse chromosome 19 (Kaupmann et al., 1991) and human chromosome 11 (Lam et al., 1991, Giovannini et al., 1993). The cDNAs for rat and rabbit CNTF code for a protein of 200 (rat) or 199 (rabbit) amino acids with a calculated molecular mass of 22.8 and $22.6 \mathrm{kD}$, respectively.

Human CNTF was cloned on the basis of these sequences (Masiakowski et al., 1991; Lam et al., 1991; Negro et al., 1991), and the protein was found to be $84 \%$ homologous to rat CNTF. CNTF revealed no similarity with the members of the neurotrophin or the fibroblast growth factor gene families. The latter was also found to support ciliary neuronal survival (Unsicker et al., 1987). However, using more sensitive pattern-matching algorithms, structural similarities of CNTF with leukemia inhibitory factor ( LIF), interleukin-6 (IL-6), oncostatin-m (OSM), and granulocyte-colony stimulating factor (G-CSF) have been proposed (Bazan, 1991). The relevance of these similarities has been underscored by the identification of a binding subunit of the CNTF receptor (CNTFR $\alpha$ ) found to be $30 \%$ homologous with the IL-6 receptor $\alpha$, and the demonstration that the CNTF recep- tor complex shares two subunits (gp 130 and LIFR $\beta$ ) with the cellular LIF receptor (for details, see Stahl and Yancopoulos, this issue).

Interestingly, and in contrast to LIF and IL-6, CNTF lacks a hydrophobic leader sequence usually found in proteins which are secreted by the classical endoplasmatic reticulum-Golgi pathway, and is not released from transfected HeLa or COS cells (Lin et al., 1989; Stöckli et al., 1989). While CNTF activity is commonly found in the supernatant of cultured astrocytes ( Lillien et al., 1988), the amount of released CNTF compared with cell-associated material is so low that it could result from unspecific release caused by cell injury or cell death within the cultures.

Although GPA activity was originally characterized in chick eye (Nishi and Berg, 1981), it was finally purified from adult chick sciatic nerves (Leung et al., 1992). The molecule identified showed $47 \%$ sequence identify with rat CNTF suggesting that this protein could be the chick homologue of CNTF. However, GPA, which like CNTF lacks a hydrophobic leader sequence, has been found to be released in small, but significantly greater quantities than CNTF from transfected cells and from isolated chorioid cells ( Leung et al., 1992). This important difference between GPA and CNTF could indicate that they are different molecules. If this holds true, then the chick homologue of CNTF as well as the rat and human GPA genes await molecular identification. Alternatively, if GPA is the chick homologue of CNTF, then a more effective release mechanism for chick CNTF than for mammalian CNTF must be assumed.

A comparison of the amino acid sequences of CNTF from different species with GPA reveals that $80 \%$ of conserved residues are found in four distinct clusters (Fig. 1). Significantly, the clusters closely correspond to the positions of the proposed $\alpha$-helices of CNTF, and add weight to the hypothesis that CNTF and GPA adopt a four helix bundle similar to that observed for growth hormone and postulated for a number of cytokines including IL6, LIF, OSM, and IL-11 (Bazan, 1991; Taga and Kishimoto, 1992).

Site-directed mutagenesis has been used to obtain some structure-function information about CNTF. CNTF analogues in which short segments of either the $\mathrm{N}$ - (up to 14 amino acids) or the C-terminus (up to 27 amino acids) have been deleted were found to be at least as active as the full-length parent molecule (Negro et al., 1994). However, longer deletions or the omission of internal 


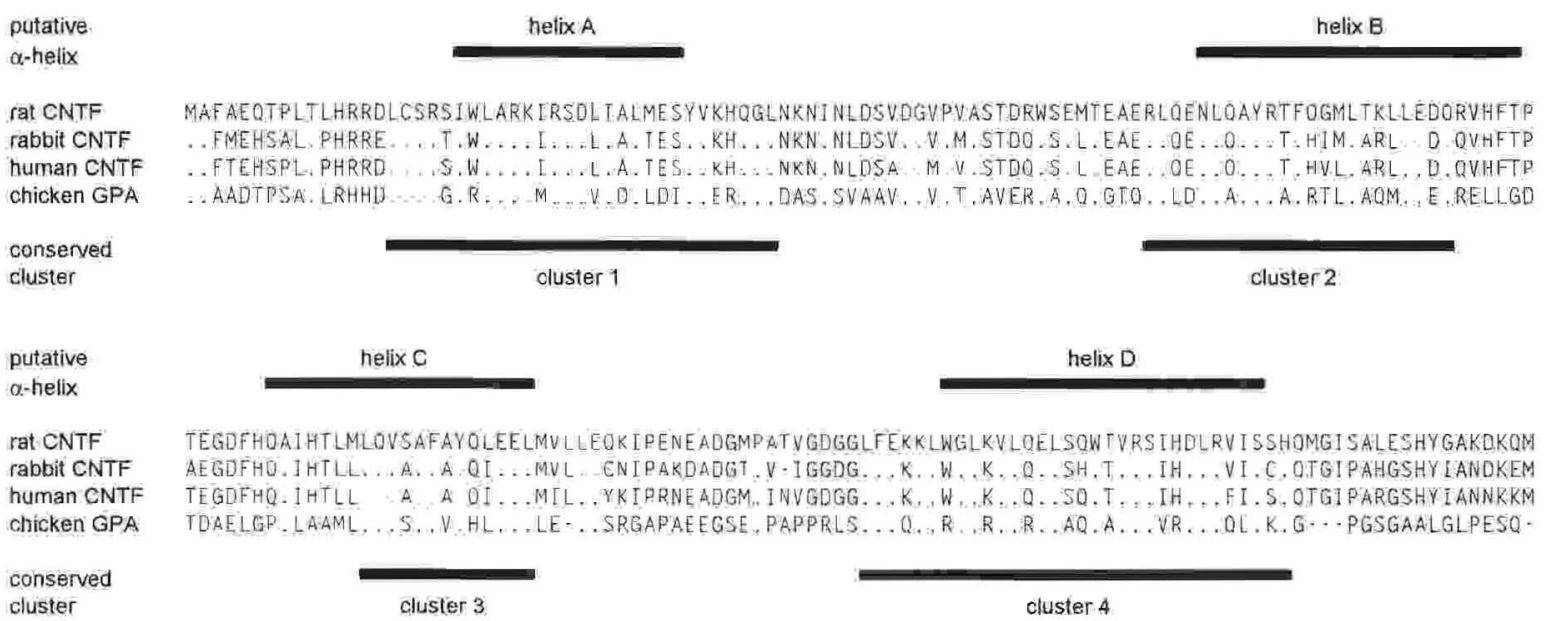

Figure 1 Comparison of the amino acid sequences of rat, human, and rabbit CNTF, and chicken GPA. Dots represent residues common to all four sequences. The position of the four putative $\alpha$-helices (Bazan. 1991), and the clusters of conserved stretches of amino acid residues are indicated by bars above and below the aligned sequences.

stretches of amino acid residues abolished biological activity. Interestingly, the truncations yielding active mutants would not be expected to interfere

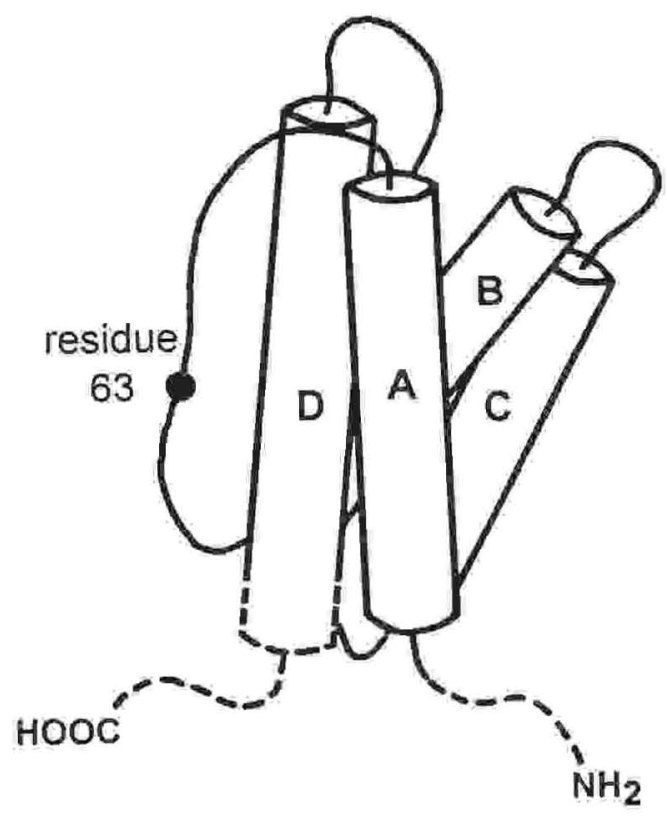

Figure 2 Model of the proposed helical structure of CNTF postulated by Bazan (1991). The four putative $\alpha$-helices A-D are depicted as cylinders. Regions from the $\mathrm{C}$ - and $\mathrm{N}$-termini which can be deleted by mutations without reducing biological activity of CNTF are shown by dashed lines. The approximate position of residue 63 , an amino acid shown to be crucial in determining the biological activity of CNTF, is indicated on the long loop connecting helices $\mathrm{A}$ and $\mathrm{B}$. with the proposed $\alpha$-helical scaffold of CNTF (Fig. 2). Indeed, the $\alpha$-helical content of the active mutants, as assessed by circular dichroism spectroscopy, was preserved. The C-terminus of CNTF can also tolerate additional residues, as CNTF proteins bearing either an epitope from c-myc (Davis et al., 1991) or three tyrosine residues at the C-terminus retain biological activity, providing further evidence that the C-terminal residues do not participate in receptor interaction (Huber et al., 1993). Similarly, the putative D helices of IL-6 and OSM, which have been proposed by modelling studies to adopt a similar fold to CNTF, have also been shown by mutagenesis analyses to be important for receptor binding and biological activities of these cytokines (Krüttgen et al., 1990 a,b; Lütticken et al., 1991; Kallestad et al., 1991). In accordance with these data, a CNTF analogue with two mutations (Gly $158 \Rightarrow$ Val; Val $161 \Rightarrow$ Ala) in the D helix was found to be without biological activity (R. Schmid and M. Sendtner, unpublished observations). In another study, a number of interspecies chimeric CNTF molecules were prepared to determine the differences between the specific biological activities and gel motilities of rat and human CNTF (Panayotatos et al., 1993). A single residue (Arg63) was found to be responsible for the higher activity of rat versus human CNTF using rat, human and chick cells ( the corresponding residue in human CNTF is Glu). Residue 63 lies on the loop between proposed helices A and B (Fig. 2 ), and it has been proposed that this region makes direct contact with components of the CNTF re- 
ceptor (Bazan, 1991), or influences the conformation of spatially adjacent residues which are involved in receptor binding. Indeed, in the recently solved structure of growth hormone. the prototypical four helix bundle protein, bound to a soluble form of its receptor shows that residues in the analogous loop between helices A and B of growth hormone do contribute directly to the binding of one of the receptor protomers (de Vos et al.. 1992). A precise understanding of the interactions of CNTF with its receptor complex awaits further mutagenesis studies and the elucidation of the structure of CNTF bound to its receptor.

\section{DEVELOPMENTAL EXPRESSION, DISTRIBUTION, AND TISSUE-SPECIFIC REGULATION OF CNTF IRRA}

By Northern blot analysis, highest levels of CNTF mRNA are detected in peripheral nerves, such as the sciatic nerve, indicating that the large amounts of CNTF protein in adult animals (Williams et al. 1984) are produced in the nerve and do not originate from retrograde transport. In newborn rats, CNTF mRNA cannot be detected (Stöckli et al., 1989 ) and the high levels of CNTF mRNA found in the adult nerve are not reached until the fourth postnatal week. Thus, the expression of CNTF mRNA and protein (Dobrea et al., 1992) parallels the differentiation of Schwann cells in the nerve (Jessen and Mirsky, 1992). CNTF mRNA cannot be detected in skeletal muscle, liver, spleen, lung of the adult rat (Stöckli et al., 1989) by Northern blot analysis of total RNA from these tissues and the very low levels detected with polyA + RNA from skeletal muscle of adult tats (Ip et al., 1993a: Giovannini et al., 1993) might well originate from Schwann cells ensheating the innervating nerve fibers within muscle (see Fig. 3). Thus, skeletal muscle does not appear to be a source of CNTF for responsive peripheral neurons, such as spinal motoneurons.

In the adult rat central nervous system, highest levels of CNTF mRNA are found in the optic nerve, olfactory bulb (Stöckli et al., 1991) and spinal cord (Ip et al., 1993a). Low but still significant levels are detectable in the brain stem, cerebellum. septum, hippocampus, striatum, midbrain, and thalamus/hypothalamus, (Stöckli et al., 199 l; Ip et al., 1993a). Other areas of the brain. in particular the frontal cortex and retina, do not contain detectable levels of CNTF mRNA.

Northern blot analysis and a PCR-based detec- tion assay did not reveal any expression of CNTF mRNA in either head or trunk of 9-day-old rat embryos (Stöckli et al., 1991). At embryonic day 18, during the period of naturally occuring cell death of spinal motoneurons, CNTF mRNA is not found in the hindlimbs or the brain, suggesting that CNTF does not play a role for the survival of motoneurons during this critical developmental period, Using very sensitive Northern blot techniques, Ip et al. (1993a) have found minute quantities of CNTF mRNA in 11-day-old rat embryos, in particular, in the head region. This would indicate that CNTF mRNA is expressed in the central nervous system during a time window between $\mathrm{E} 9$ and $\mathrm{E} 18$. However the physiological function (if any) of CNTF during this time remains to be established. CNTF might contribute to the terminal differentiation of neuronal precursor cells, as has been observed with peripheral sympathetic precursor cells in culture, which become postmitotic and acquire cholinergic properties in the presence of CNTF (Ernsberger et al., 1989).

Hitherto only few studies have appeared on the tissue localization of CNTF mRNA by in situ hybridization. In the sciatic nerve, CNTF mRNA is localized in stripe-like structures resembling the perinuclear regions of Schwann cells (Friedman et al., 1992). This is in agreement with data on the immunhistochemical location in Schwann cells (see below). In the central nervous system. CNTF mRNA has been identified adjacent to the glia limitans at the ventral surface of the midbrain (Ip et al., 1993a), with no signal detectable in cortex and hippocampus (Ip et al., 1993b).

Interestingly, the regulation of CNTF mRNA in the peripheral and central nervous systems is distinctly different. After peripheral nerve lesion, CNTF mRNA drops dramatically to less than 5\% within the first week after nerve lesion (Sendtner et al., 1992a; Friedman et al., 1992: Seniuk et al., 1992). After nerve crush allowing regeneration, the CNTF mRNA level slowly recovers, the first positive cells being detectable by immunohistochemistry and in sim hybridization 1 week after lesion. Northern blot analysis reveals a significant increase in CNTF $\mathrm{mRNA}$ at about 4 weeks after lesion (Sendtner et al., 1992a; Friedman et al., 1992).

In contrast to the down-regulation of CNTF mRNA in the distal nerve after lesion, CNTF mRNA is rapidly up-regulated in the central nervous system of the adult rat after lesion of the hippocampus or the cortex. The increase in CNTF mRNA is maximal 3 days after lesion, and both 

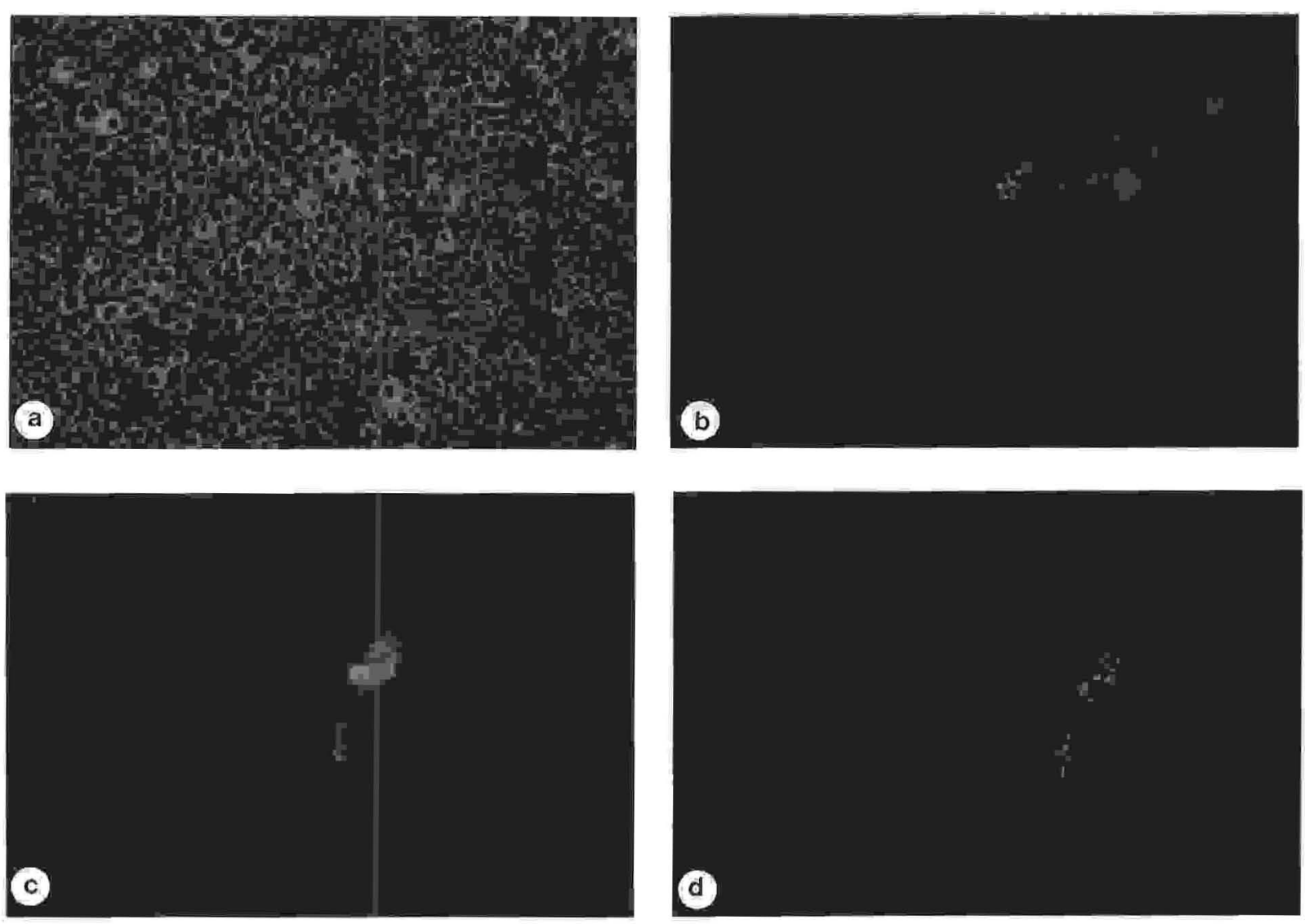

Figure 3 Immunolocalization of CNTF in the sciatic nerve (a), the superior cervical ganglion (b). and skeletal muscle (c. d). A polyclonal antiserum against recombinant rat CNTF stains the cytoplasm of myelinating Schwann cells within the sciatic nerve (a). Only few myelinating Schwann cells within the superior cervical ganglion are CNTF-positive, whereas the nonmyelinating Schwann cells and neuronal cell bodies within the superior cervical ganglion are not stained (b). Also within skeletal muscle, CNTF immunoreactivity is located in myelinating Schwann cells (c) of inmervating nerve fibers, which are identified by doublestaining witl a monoclonal antibody against neurofilament (d). Muscle fibers are unstained.

CNTF mRNA and protein levels are sustained for at least 3 weeks. In the lesioned rat brain. CNTF seems to be produced by reactive astrocytes around the wound cavity (lp et al., 1993b).

Unlike Schwann cells in the intact nerve. Schwann cells in culture produce very low levels of CNTF mRNA (Carroll et al., 1993), although substantial amounts of CNTF-like biological activity can be detected in Schwann cell conditioned medium (Meyer et al., 1992). In this way, with regard to CNTF expression. cultured Schwann cells mimic the situation in early postnatal peripheral nerve development or after peripheral nerve lesion where CNTF mRNA levels are also low. Thus, Schwann cell CNTF expression is correlated with the more mature myelinating state, and since Schwann cell differentiation is thought to be in- duced by innervation, it may be hypothesized that neuron-Schwano cell signalling is involved in the regulation of CNTF expression. Whether low CNTF levels in cultured Schwann cells reflects the fact that the cells are cultured from newborn animals and have not yet begun to express CNTF or because the cells lack contact with neurons is not clear. Stimulation of the cAMP second messenger pathway in cultured Schwann cells has been shown to induce a transient expression of molecules characteristic of the more mature myelinating Schwann cells, for example, P0, MBP ( see Jessen and Mirsky. 1991 for review). However, such treatments fail to increase CNTF mRNA levels in these cultures (Carroll et al., 1993). Thus, the signals that induce CNTF expression in Schwann cells are as yet unknown. 
CNTF mRNA is readily detectable in astrocyteenriched brain cell cultures from several different brain regions (Rudge et al., 1992; Carroll et al.; 1993, Rudge et al., 1994). Mechanical injury to the adult rat brain causes a marked increase in CNTF mRNA and protein in cells which most probably are astrocytes undergoing reactive gliosis at the site of injury (Ip et al., 1993b). Since astrocytes in culture display several traits characteristic of reactive astrocytes (for review see McMillian et al., 1994), the above observation may explain the high CNTF expression in cultured astrocytes. Of a large number of factors and treatments applied in order to try to alter the expression of CNTF in rat astrocytes (Carroll et al., 1993; Rudge et al., 1994), only the cytokine IFN- $\gamma$ (Carroll et al., 1993) and treatment with the anti-Parkinson's drug deprenyl in combination with mechanical injury (Seniuk et al., 1994) were able to cause a modest two- to threefold increase in CNTF mRNA expression. The effect of IFN- $\gamma$ on CNTF expression might be part of the general response of astrocytes to invasion of the CNS by cells of the immune system during injury, since IFN- $\gamma$ is not present in the brain under normal circumstances. CNTF mRNA levels in astrocytes can be reduced by several treatments including activation of adenylate cyclase. stimulation of $\beta$-adrenergic receptors, and treatment with various members of the fibroblast growth factor family (Carroll et al., 1993: Rudge et al., 1994). Since activation of adenylate cyclase and the adrenergic receptor systems are involved in many of the neurotransmitter-mediated actions of neurons, it may be that in the uninjured brain, CNTF mRNA levels are down-regulated by neuron-astrocyte interactions and that the increase in CNTF in astrocytes after brain injury is a consequence of loss of neuronal suppression. The negative effect of FGFs on CNTF mRNA expression in vitro may be due to the fact that although astrocytes in culture produce bFGF. they probably do not secrete it (Hatten et al., 1988: Woodward et al., 1992).

\section{IMMUNODETECTION OF CNTF IN TISSUES OF THE POSTNATAL RAT}

As most of the CNTF protein produced in cells is not secreted, immunohistochemistry is a favorable method to determine tissue and cellular localization of CNTF protein. A variety of polyclonal and monoclonal antibodies against CNTF have been developed and used for immunohistochemistry with various tissues, in particular of the adult rat.

In all the studies carried out so far, polyclonal and monoclonal antibodies have demonstrated strong CNTF immunoreactivity within the cytoplasm of adult rat myelinating Schwann cells (see Fig. 3). No signal was detected in the nuclei and myelin-sheaths of these cells, in axons, or vascular, endoneural and perineural cells (Stöckli et al., 1991; Dobrea et al., 1992; Friedman et al., 1992) (Fig. 2). In the CNS, CNTF immunoreactivity is found in astrocyte-like cells within the optic nerve (Stöckli et al., 1991). The identity of these cells was confirmed by co-staining with GFAP (Dobrea et al., 1992). In the olfactory bulb, CNTFimmunoreactivity is detectable in ensheathing cells (Stöckli et al., 1991) - specific glial cells with many Schwann cell like properties-and in the spinal cord of the adult rat. CNTF immunoreactivity was detected within radial glia in grey matter (Dobrea et al., 1992).

When peptide antisera against different regions of the CNTF protein were used, in some cases additional structures were found to be immunoreactive within the PNS and the CNS of the adult rat, depending on the peptide chosen for immunization. For example, several antisera raised against AA 186-199 of the rat CNTF sequence showed significant staining of axons within the sciatic nerve of the adult rat ( $M$. Sendtner and B. Holtmann unpublished observations). Hawever, preadsorption of these antisera with CNTF could not abolish the staining. Similarly, the diffuse staining of myelin and the nuclei of Schwann cells and fibroblasts observed with antisera against AA 115-126 of rat CNTF could be eliminated by preadsorption with the corresponding peptide but not with recombinant CNTF (B. Holtmann and M. Sendtner, unpublished observations). Western blot analysis of adult rat sciatic nerve extracts showed that these two peptide antisera stained bands in addition to the single $23 \mathrm{kD}$ immunoreactive band observed with monoclonal anti CNTF antibody (4-68 and 4-65) (Stöckli et al., 1991; Sendtner et al., 1992a) and with a rabbit antiserum raised against recombinant rat CNTF (K10). Presumably these two antisera raised against peptide sequences from CNTF can cross-react with other molecules.

Rende et al. ( 1992 ) have used two peptide antisera against CNTF (Serum A: AA45-59, Serum B: AA 181-200) for their immunohistological study of CNTF location in peripheral nerves. In Western 
blots of rat sciatic nerve extracts, affinity-purified antibodies from both antisera recognized a single band between 20 and $30 \mathrm{kD}$ at the same position as recombinant or purified rat CNTF. Antibodies against peptide 45-59 recognized an additional band at $200 \mathrm{kD}$ which was not observed with the antiserum against the C-terminus (AA-181-200). When used for immunohistochemistry, these two antisera stained the cytoplasm of both myelinating and nonmyelinating Schwann cells, and at a higher concentration, also the axons. We also observed axonal staining with a peptide antiserum against AA 186-199 of rat CNTF. CNTF-like immunoreactivity was not detected in nonmyelinating Schwann cells using similar (Dobrea et al., 1992) or different antibodies (see Fig. 3). Since Northern blot analysis of the sympathetic paravertebral trunk (which contains many unmyelinating Schwann cells) did not reveal expression of CNTF mRNA, it is likely that the staining of the unmyelinating Schwann cells might be due to cross-reactivity of CNTF epitopes shared with other molecules.

Henderson et al. (1994) have developed an antiserum against a peptide derived from AA 131-147 of the rat CNTF sequence. Affinity-purified antibodies from this serum recognized purified rat sciatic nerve CNTF as a single band in Western blots. However, in extracts from C6 glioma cells and astrocytes, additional bands were observed. Using these antibodies, immunoreactive neurons were detected in the facial nucleus, dentate gyrus, olfactory bulb, basal forebrain, locus coeruleus, hippocampus, cerebellum (Purkinje cells), cortex, and substantia nigra. Neuronal CNTF immunoreactivity was observed predominantly in the nucleus. which is in contrast to the results obtained with myelinating Schwann cells. In the olfactory bulb, neurons are not stained with monoclonal antibodies 4-68 and 4-65 and polyclonal anti-CNTF antisera (Stöckli et al., 1991, B. Holtmann and M. Sendtner, unpublished results). At present, the existence of low quantities of CNTF which cannot be detected with our antisera cannot be excluded. In the hippocampus, dentate gyrus, and cortex, the amounts of CNTF protein and biological activity are much lower than in the sciatic nerve, and in situ hybridization using specific probes for CNTF mRNA do not reveal a distinct signal in these regions of the intact adult rat (lp et al., 1993a,b). Also, the CNTF mRNA levels detectable by Northern blot analysis are extremely low in these areas (Stöckli et al., 1991). Thus at present, the results demonstrating neuronal and nuclear loca- tions of CNTF-like immunoreactivity should be interpreted with caution.

\section{THE EFFECTS OF CNTF ON NEURONAL DIFFERENTIATION AND SURVIVAL}

Initial results with partially purified CNTF indicated that it promotes the survival of a broad spectrum of cultured neurons, for example, E8 ciliary neurons, E 10 and E 11 chick sympathetic and sensory neurons (Manthorpe et al., 1982). These results were confirmed later with purified and recombinant CNTF (reviewed by Manthorpe and Varon, 1985, Sendtner et al., 1991), and the list of CNTF responsive neurons was extended to $\mathrm{E} 8$ chick nodose neurons and the different populations of Elo chick trigeminal neurons. E8 chick DRG neurons, while supported by NGF and BDNF in culture, are unresponsive to CNTF. However, at E10, CNTF promotes the survival of more than $40 \%$ DRG neurons (Manthorpe et al., 1982). Similar observations were also made with chick spinal motoneurons. Motoneurons isolated at E4 cannot be supported by CNTF (Longo et al., 1982, BlochGallego et al.. 1991), whereas at E6, more than $60 \%$ of motoneurons purified by metrizamide gradient centrifugation survive in the presence of CNTF (Arakawa et al., 1990).

Several observations also indicate that CNTF can induce specific properties of developing neurons without affecting their survival. Cultured statoacoustic neurons from E5 chick embryos do not survive in the presence of CNTF, but respond with increased fiber outgrowth (Bianchi and Cohan, 1993). Also, newborn mouse nodose neurons do not survive in the presence of CNTF in cell culture (Manthorpe et al., 1986), although these cells express high levels of CNTFR $\alpha$ (Ip et al., 1993a). Likewise, the survival effect of CNTF on cultured rat motoneurons isolated and enriched from E15 rat is very low (Hughes et al., 1993), while motoneurons from E14 rat react to CNTF with significant induction of ChAT (Magal et al., 1991; Wong et al., 1993), at least in mixed cultures.

The effect of CNTF on cholinergic neuronal differentiation has been described with E7 chick sympathetic neuronal precursor cells. These cells are still capable of entering mitosis and at this stage do not yet depend on neurotrophic factors for their survival in culture. CNTF blocks cell division and induces VIP immunoreactivity in these cells (Ernsberger et al., 1988). Similarly, although CNTF 
cannot maintain the survival in vitro of sympathetic neurons from newborn rats for a period of 1 week (Saadat et al., 1989), these neurons respond to CNTF by induction of ChAT during the same culture period, suggesting that functional CNTF receptors and signal transduction are present on these cells. This effect on ChAT induction is similar to the response to LIF (Yamamori et al., 1989; Patterson, 1992). Interestingly, although both CNTF and LIF share two receptor subunits, there are subtle differences in how these two factors act on sympathetic neurons: The action of LIF on cholinergic differentiation can be blocked by depolarization of the neurons, whereas the action of CNTF cannot. indicating that $\mathrm{Ca}^{2+}$ influx could play a role in LIF but not in CNTF signal transduction in sympathetic neurons (Rao et al., 1992). It is not clear whether the effect of CNTF on neuronal differentiation also occurs in vivo. Mice in which endogenous CNTF expression has been abolistied by homologous recombination of the CNTF gene show normal cholinergic differentiation of sympathetic neurons innervating the sweat glands (Masu et al. 1993). It remains to be established whether CNTF deficiency can be compensated during neuronal differentiation by other molecules or mechanisms. The early expression of CNTFR $\alpha$, the binding subunit of the CNTF receptor complex in neurons (Ip et al., 1993a), starts well before they show survival responses. This is surprising in view of the results obtained with the CNTF knock-out mice, in which no early developmental changes could be observed (see below). It is thus possible that the effects of CNTF on early neuronal differentiation and survival during embryonic development mimic the function of another CNTF-like molecule, Such a molecule would be expected to be expressed very early, to be secreted, to share the CNTF receptor, and to be the physiological mediator of effects that can be observed with CNTF in cell cultures of isolated early embryonic neurons.

As a step to analyze whether effects of CNTF on embryonic neurons are of physiological importance, CNTF was administered in vivo. When added in ovo to developing chick embryos between E5 and E9, a significant increase of the number of spinal motoneurons could be observed, indicating that the survival effect on CNTF on embryonic chick motoneurons also occurs in vivo. Interestingly, the number of dorsal root sensory, paravertebral sympathetic, nodose or sympathetic preganglionic neurons (Oppenheim, 1991) was unchanged. When CNTF was added between E9 and E14, during the period of naturally occurring cell death of ciliary neurons, the number of surviving ciliary neurons was not increased, indicating that their survival cannot be increased by exogenous CNTF.

It is difficult to understand why the survival of spinal motoneutons should be increased by CNTF. whereas that of ciliary neurons and other CNTF responsive cells should not. Are the effects of CNTF on the survival of motoneurons a pharmacological effect or do they indeed reflect a physiological function? This question is not yet resolved, but can now be studied in mice in which the expression of CNTF has been abolished by gene targeting. Such mice lacking endogenous CNTF expression appear normal at birth, and the number of motoneurons is unchanged in 4-week-old animals. This suggests either that CNTF does not play a crucial role for motoneurons during embryonic development or that the lack of CNTF is fully compensated for by other, as yet unidentified factors. However, in postnatal mice, atrophy and loss of motoneurons is detectable between the fourth postnatal week and 6 months (Masu et al., 1993). During this time, motoneurons shrink and about $30 \%$ of motoneuron are lost, as determined by facial motoneuron counts from brain stem serial sections from these animals. This indicates that CNTF is indeed important for postnatal survival and functional integrity of motoneurons. Presumably, CNTF is released from the cytoplasm of synthesizing cells following. for example. microtrauma which transiently disrupts the cell membranes of astrocytes and Schwano cells. Alternatively, other specific cellular release mechanisms might exist which have yet to be elucidated.

In the rat, the period of naturally occurring cell death of spinal motoneurons starts at E15 and is completed between birth and postnatal day 3 (Oppenheim, 1986). At birth, endogenous levels of CNTF mRNA are still very low, and motoneurons are known to be highly sensitive to injury. More than $85 \%$ of lesioned facial motoneurons die within 1 week after axotomy. The high vulnerability of motoneurons decreases during the first 4 weeks after birth while CNTF expression by myelinating Schwann cells increases. When supplied locally to transsected facial nerves of newborn rats (Sendtner et al., 1990), CNTF can very efficiently rescue the survival of the corresponding injured motoneurons. In adult rats, retrograde transport of CNTF is increased after peripheral nerve injury in dorsal root sensory and spinal motoneurons (Curtis et al., 1993). Thus it is possible that one of the physiological functions of endogenous CNTF in pe- 
ripheral nerves of adult rodents is to act as a "lesion factor" for injured motoneurons (Thoenen, 1991).

A variety of additional CNTF-responsive neuronal populations have been identified in the central nervous system. In cell culture, CNTF increases the survival of various populations of hippocampal neurons isolated from E18 rat embryos, including GABAergic and cholinergic neurons (Ip et al., 1991). Increased TH levels, without effects on neuronal survival, were observed in noradrenergic neurons in cultures derived from embryonic rat locus coeruleus when CNTF was added together with norepinephrine (Louis et al., 1993a). Similarly, in cultures of E16 rat substantia nigra neurons, CNTF was not able to support long-term survival of TH-positive cells but showed a significant effect on TH immunoreactivity after 3 days in culture (Magal et al., 1993a). Similar transient effects were observed with corticospinal neurons from newborn rats: A significant survival effect was only seen after 2 days in culture, but after that time, survival in the presence of CNTF declined (Magal et al., 1993b). Additional CNTF responsive neurons have been identified in adult rats after transsection of axonal projections of different neuronal populations. For example, neurons of the anterodorsal and anteroventral thalamic nuclei can be rescued by CNTF infusion after transsection of their axonal projections in the cingulum bundle (Clatterbuck et al., 1993). Similarly, dopaminergic neurons of the substantia nigra respond to CNTF after transection of the nigrostriatal pathway (Hagg and Varon, 1993a). Also various populations of septal neurons, including the cholinergic neurons of the medial septum. could be rescued by CNTF after fimbria fornix transsection (Hagg et al., 1992). However, the response to CNTF differed to that of NGF in that CNTF acted on the survival of a much broader spectrum of septal neurons, not only the cholinergic neurons, and did not induce ChAT activity.

To test for protective effects of CNTF, most lesion paradigms so far have used mechanical transsection of neuronal projections leading to retrograde atrophy and degeneration of corresponding cell bodies. However, experimental evidence is increasing so that CNTF ean also protect neurons against injury by other means. For example, in cultures of embryonal hippocampal neurons CNTF reduces the sensitivity to glutamate toxicity (Skaper et al., 1992), and, in vivo. photoreceptors of adult rats can be protected by CNTF against the damaging effects of constant fluorescent light (LaVail et al., 1992). Thus CNTF displays protective effects for a variety of central and peripheral neurons following a variety of treatments that would otherwise lead to neuronal damage.

\section{CNTF EFFECTS ON NONNEURONAL CELLS}

The spectrum of CNTF-responsive cells includes not only neutons but also nonneuronal celis. Among them are glial cells such as oligodendrocytes and their precursors, microglial cells, a variety of other cells from different organs such as skeletal muscle, liver, bone marrow, and even embryonic stem cells. This could partially be explained by specific properties of the CNTF receptor which shares the two signal transducing components with the LIF receptor, namely, gp 130 and the LIF receptor $\beta$ (Davis et al., 1993a). As these two subunits are widely expressed, in particular in the liver, bone marrow, fat tissue, and the central nervous system, it is logical to conclude that CNTF responsive cells can be identified by the expression of the third component of the CNTF receptor, CNTFR $\alpha$ (see Stahl and Yancopoulos, this issue). Initial experiments have shown that CNTFR $\alpha$ is expressed only in the nervous system and in skeletal muscle and not in the liver (Davis et al.. 1991). This was confirmed by in situ hybridization experiments that revealed that CNTFR $\alpha$ is expressed widely throughout the adult peripheral and central nervous systems, with most of the expression localized to neuronal cells; no significant hybridization signals were observed in nonneuronal cells, including astrocytes, or oligodenrocytes in CNS white matter (Ip et al., 1993a).

Thus the known effects of CNTF on oligodendrocyte differentiation and on other nonneuronal cells would appear difficult to explain with this simple model. Subsequent experiments showed that several cell lines expressing gp130 and LIFR $\beta$ could also respond to CNTF in the absence of CNTFR $\alpha$, indicating that CNTFR $\alpha$ is not an absolute prerequisite for CNTF signal transduction (Davis et al., 1993b; Gearing et al., 1994). However, the CNTF response was observed at high ligand concentrations and it is not clear whether these high concentrations, necessary for a cellular response of cells expressing only gp 130 and LIFR $\beta$ in the absence of CNTFR $\alpha$, are ever reached in vivo. A more likely explanation might be that the expression of CNTFR $\alpha$ in these cells is so low that it cannot be detected by in situ hybridization. Very low expression of CNTFR $\alpha$ mRNA. (Ip et al., 
1993a) has now also been shown in liver cells which react to CNTF by induction of acute phase proteins, both in vitro (Schooltink et al., 1992; Nesbitt et al., 1993) and in vivo (Dittrich et al., 1994). This could also be the case in oligodendrocytes and their precursor cells. Alternatively, CNTFR $\alpha$ might not be expressed by oligodendrocytes but available in soluble form from other cells (Davis et al., 1993b), and thus be able to form a functional receptor after association with $\mathrm{gpl} 30$ and LIFR $\beta$ on the cell surface. This is unlikely, as purified oligodendrocytes cultured in the absence of contaminating cells and in serum-free medium, can respond to CNTF with increased survival (Barres et al., 1993a). It is important to note that the concentrations of CNTF necessary for the effects of CNTF on cultured oligodendrocytes are in a range from 5 to $100 \mathrm{pg} / \mathrm{mL}$, indicating that the effect of CNTF on oligodendrocyte survival is mediated by high-affinity receptors and not by low-affinity receptors formed by $\mathrm{gp} I 30$ and LIFR $\beta$.

Initial observations that $\mathrm{CNTF}$ affected the differentiation of oligodendrocyte precursor cells were made with bipotential precursor cells which responded in culture to the addition of CNTF with the induction of GFAP (Hughes et al., 1988). The induction of CNTF was transient only, and stable induction of GFAP in these cells was observed only when components of the extracellular matrix were added together with CNTF (Lillien et al., 1990). In the optic nerve, CNTF mRNA expression starts during the first postnatal week, and the levels of CNTF mRNA and bioactivity remain high up to adulthood (Stöckli et al., 1991). Most of the oligodendrocytes within the optic nerve are generated postnatally, and a significant number of oligodendrocytes degenerate during a period of several weeks after birth (Barres et al., 1992). In cell culture, isolated oligodendtocytes are dependent on multiple survival factors from several gene families: CNTF (Louis et al., 1993; Barres et al., 1993a) LIF and IL-6; neurotrophin-3 (Barres et al., 1994) and insulin-like growth factors- 1 and -2 (Barres et al., 1992). Interestingly, CNTF prevents both natural and tumor necrosis factor-induced cell death of cultured oligodendrocytes, both of which are apoptotic, but not necrotic cell death induced by complement (Louis et al.. 1993). Also in vivo. CNTF, members of the IGF gene family and neurotrophin- 3 can increase the number of surviving oligodendrocytes, indicating that all these factors could have a regulatory function for oligodendrocyte survival during postnatal life (Barres et al., 1993b, 1994).
Besides its role on survival and differentiation of glial cells, CNTF also affects properties of a number of other cell types. For example, isolated and purified microglial cells in culture react to CNTF and LIF by induction of CD4, and the infusion of CNTF into the brain induces CD 4 and CR 3 complement receptor immunoreactivity in resting $\mathrm{mi}$ croglia, indicating that they can be activated to a reactive, phagocytotic phenotype (Hagg et al., $1993 \mathrm{~b}$ ) by CNTF. Liver cells react by induction of acute phase genes, further illustrating the role that CNTF could play in inflammatory responses, at least when administered at pharmacological concentrations. It is not clear whether these cells express CNTFR $\alpha$ or whether soluble CNTFR $\alpha$ is necessary for these effects.

The only nonneuronal cells known to express high amounts of CNTFR $\alpha$ are skeletal muscle cells (Davis et al., 1992). These cells also express functional LIF receptors, as murine and human myoblasts in culture are known to respond to LIF by an increase of proliferation (Austin et al., 1991, 1992). After denervation, CNTFR $\alpha$ mRNA is rapidly up-regulated in skeletal muscle (Davis et al., 1993), and daily subcutaneus administration of CNTF could diminish denervation-induced weight loss of the soleus muscle by about $50 \%$ (Helgren et al., 1994), at least during the first week after denervation. It has been suggested that CNTF from Schwann cells could act as a physiological myotrophic factor for skeletal muscle (Ip and Yancopoulos. 1992: Helgren et al., 1994). However, it is not clear whether this effect of CNTF occurs also under physiological conditions, and whether the endogenous levels of CNTF which could be released from Schwann cells are high enough to affect denervated muscle fibers. Transgenic mice lacking endogenous CNTF expression apparently do not show any reduction in body weight that would be expected after reduction of the muscle mass. It would be interesting to test the possibility of enhanced muscle atrophy after section of the motor axons in these mice.

\section{CLINICAL ASPECTS: CNTF AS A DRUG CANDIDATE FOR THE TREATMENT OF NEUROMUSCULAR DISORDERS}

The finding that CNTF can promote the survival of embryonic and postnatal motoneurons in cell culture (Arakawa et al., 1990; Martinou et al., 1992), during normal development (Oppenheim et al., 1991) and postnatally after peripheral nerve 
lesion (Sendtner et al., 1990) has raised the question whether this protein could also be used for treatment of patients with degenerative motoneuron disorders.

The molecular defect responsible for the degeneration of motoneurons in patients is known in only few cases. A subgroup of patients with familial amyotrophic lateral sclerosis (ALS) has been found to have mutations in the superoxide dismutase gene (Rosen et al., 1993) and in patients suffering from an X-linked form of spinal muscular atrophy, an alteration of the androgene receptor gene has been observed (La Spada et al., 1991). The molecular defect $(\mathrm{s})$ responsible for the large majority of sporadic eases of motoneuron disorders (in particular ALS) remain(s) unclear.

Several mouse mutants have been used to test the effectiveness of CNTF in interfering with the mechanism leading to degeneration of motoneurons, including the wobbler (Mitsumoto et al, 1992), motoneuron degeneration ( $m n d$ ) (Helgren et al., 1992), and progressive motoneuronopathy ( pmn) (Sendtner et al.. 1992b,c) mouse mutants. The gene defects responsible for the motoneuron disorders of these mice are still unknown, but they are independent of each other. Only for the mnd mouse, which suffers from a late-onset motoneuron disorder with slow progression, has a mechanism responsible for the motoneuron degeneration (neuronal ceroid lipofuscinosis) been proposed (Bronson et al., 1993).

In all three mouse mutants, CNTF has been reported to improve motoneuron function, although the CNTF gene is not involved in these mice and, at least in wobbler and pmn mice, CNTF expression is not altered (Kaupmann et al.. 1991; M. Sendtner, unpublished observations).

In pmn mice continuous treatment with CNTF starting at the end of the third postnatal week when the first signs of muscle weakness are detectable in the hindlimbs, leads to rescue of more than $30 \%$ of the motoneurons which would otherwise degenerate during the following 3 weeks. Furthermore. CNTF increases the number of myelinated axons in the phrenic nerve and leads to improved motor function (Sendtner et al., 1992b,c), indicating that it not only influences the survival of the motoneuron cell bodies but also axonal integrity, regeneration, and presumably also synaptic activity of the motoneurons. A significant effect of CNTF on motoneuton function has also been observed in $m$ nd and wobbler mice (Helgren et al., 1992; Mitsumoto et al., 1992).

We have observed that daily subcutaneous in- jection of CNTF was much less effective in pmn mice than continuous supply by intraperitoneally implanted cells producing and secreting high amounts of CNTF. This could be due to the short half-life of CNTF in the circulation. In adult rats, radioactively labelled CNTF has an initial plasma half-life of less than 3 min when injected intravenously (Dittrich et al., 1994). When administered subcutaneously, CNTF concentrations in the circulation reach a peak between 30 and $60 \mathrm{~min}$ later, and decline to undetectable levels at $8 \mathrm{~h}$ after subcutaneous injection (Helgren et al.. 1994). After intravenous injection, most of the radiolabelled CNTF was found in the liver following its association with soluble plasma proteins. One of these CNTF binding proteins in the blood is probably the soluble CNTFR $\alpha$, the other has been demonstrated to be $\alpha 2$ macroglobulin (Liebl et al.. 1993: Dittrich et al.. 1994). A complex of CNTF and the soluble CNTFR $\alpha$ could bind to the many cell types expressing gp 130 and LIFR $\beta$, in particular, tiver cells, macrophages, adipocytes, and bone marrow cells, and induce effects similar to those of LIF. Mice treated continuously with LIF become severely sick and suffer from cachexia, excess new bone formation, calcification of skeletal muscle, and other pathological manifestations (Metcalf and Gearing, 1989). While such side effects would also be expected when CNTF is administered systemically, mouse mutants treated with CNTF for several weeks do not show such severe symptoms. However it cannot be excluded that such effects are possible in other species. For example, injection of CNTF into rabbits induces fever (Shapiro et al., 1993), and in rats, the mRNAs for acute-phase proteins, such as haptoglobin, are rapidly up-regulated in the liver after intravenous injection of CNTF (Dittrich et al., 1994). This response is presumably mediated by specific CNTF receptors, since CNTF can be cross-linked on liver cell membranes to three proteins with the typical characteristics of the subunits of the CNTF receptor.

Clinical studies with CNTF in patients with amyotrophic lateral sclerosis were started in 1992. CNTF was injected subcutaneously into patients every other day at a concentration up to $30 \mu \mathrm{g} / \mathrm{kg}$ of body weight. Side effects. such as fever, cough, and local reactions, at the injection site were detectable, but they could apparently be tolerated by the patients. Initial reports from 12 patients treated for 4 months with CNTF showed very encouraging results (Brookes et al.. 1993). Loss of muscle strength during this period was about three times lower in patients treated with CNTF in compari- 
son to patients that had received placebo. However, results varied greatly from patient to patient. which could mean that some patients had benefits from the CNTF treatment, whereas others suffered from the side effects without any improvement in motor function. Thus, to improve the clinical effectiveness of CNTF, its administration needs to be optimized. For example, intrathecally administered CNTF would be expected to be more efficiently taken up by motoneurons than CNTF from the circulation. Side effects resulting from actions of CNTF on liver cells and macrophages could be reduced. However, CNTFR $\alpha$ has also been found in significant quantities in cerebrospinal fluid (Davis et al., 1993b), and CNTF might exert a series of undesired side effects such as sterile meningitis caused by the activation of microglia (Hagg et al., 1993b). CNTF availability might also be improved by continuous administration, as discussed for the mouse model pmn. Finally, combination with other motoneuron survival factors such as BDNF, NT-4/5 or IGF-I (Thoenen et al., 1993) could prove useful. The appropriate combination of motoneuron survival factors in lower concentrations could elicit the same therapeutic response as larger amounts of a single factor. thus reducing the likelihood of side effects.

We thank Yues-Alain Barde, Georg W. Kreutzberg from the Max-Planck-Institute in Martinsried, and Ron Lindsay, Jesse Cedarbaum, and Len Schleiffer from Regeneron Pharmaceuticals, Tarrytown. New York, for helpful discussions.

\section{REFERENCES}

ADLER, R., LANDA. K. B.. MANTHORPE, M., and VARON, S. ( 1979). Cholinergic neurotrophic factors: intracular distribution of trophic activity for ciliary neurons. Science 204:1434-1436.

Allsope, T. E., Robinson, M., WYATt. S. and DAVIES, A. M. (1993a). Ectopic trkA expression mediates a NGF survival response in NGF-independent sensory neurons bat not in parasympathetic neurons. $J$. Cell Biot. 123:1555-1566.

Allsopp, T. E., Wyatt. S. Paterson, H. F., and DaVIES, A. M. (1993b). The protooncogene bel-2 can selectively rescue neurotrophic factor-dependent neurons from apoptosis. Cell 73:295-307.

ARAKAWA, Y., SEndtner, M., and Thoenen, $H$. (1990). Survival effect of ciliary neurotrophic factor (CNTF) on chick embryonic motoneurons in culture: comparison with other neurotrophic factors and cytokines. I. Neurosei. 10:3507-3515.
Austin. L. and Burgess, A. W. (1991). Stimulation of myoblast proliferation in culture by leukaemia inhibitory factor and other cytokines. $J$. Neurol. Sci. 101: 193-197.

Austin, L., Bower. J.. Kurek, J., and VAKakis. N. (1992). Effects of leukaemia inhibitory factor and other eytokines on murine and human myoblast proliferation. J. Neurol. Sci. 112:185-191.

Bader, C. R., Bertrand, D. and Kato, A. C. (1982). Chick ciliary ganglion in dissociated cell culture. II Electrophysiological properties. Dev. Biol. 94:131141.

BARBIN, G., MANTHORPE. M.. and VARON, S. (1984). Purfication of the chick eye ciliary neuronotrophic factor. $J$. Neurochem. 43:1468-[478.

Barres, B. A., Hart, I. K., Coles. H. S. R., Burne, J. F., VOYvodic, J. T.. RICHARDSON, W. D. and RAFF, M. C. (1992). Cell death and control of cell survival in the oligodendrocyte lineage. Cell 70:31-46.

BARRES, B. A. SCHMID, R., SENDTNER, M., and RAFF, M. C. (1993a). Multiple extracellular signals are required for long-term oligodendrocyte survival. Development 1 18:283-295.

BARRES, B. A., JaCOBSON. M. D., SCHMID, R., SENDTNER, M., and RAFF, M.C. (1993b). Does oligodendrocyte survival depend on axons? Current Biol. 3:489-497.

Barres. B. A.. RafF, M. C., Gaese, F., Bartke. I.. DeCHANT, G., and BARDE. Y.-A. (1994). A crucial role for neurotrophin-3 in oligodendrocyte development. Nature $367: 37$ l-375.

BAZAN, I. F. (1991). Neuropoietic cytokines in the hematopoietic fold. Neuron 7:197-208.

BETz, W (1976). The formation of synapses between chick embryo skeletal muscle and ciliary ganglia grown in vitro. J. Physiol. 254:63-73.

Bianchi, L. M, and COHAN, C. S. (1993). Effects of the neurotrophins and CNTF on developing statoacoustic neurons: comparison with an otocyst-derived factor. Dev. Biol. 159:353-365.

Bloch-Gallego. E. Huchet. M., El M'Hamd, H., XiE, F.-K.. TanakA, H., and Henderson, C. E. (199]). Survival in vitro of motoneurons identified or purified by novel antibody-based methods is selectively enhanced by muscle-derived factors. Development 11:221-232.

Bronson, R. T., Lake, B. D.. CoOK. S., TaYlor, S., and DAVISSON, M. T. (1993). Motor neuron degeneration of mice is a model of neuronal ceroid lipofuscinosis (Batten's disease). Ann. Netrol. 33:381-385.

BROOKES, B. R.. SANIAK, M., MITSUMOTO, H. SZIRONY, K., NeVILle, H. RINGEL, S., BRINKMANN, J., Pestronk, A., Florence, J., Cedarbaum, J., CharAtan. M., Stambler, N., WTt tes, J., and Brittain, E. (1993). Recombinant human ciliary neurotrophic factor (rhCNTF) in amyotrophic lateral sclerosis (ALS) patients: Dose selection strategy in phase I-II 
safety, tolerability and pharmakokinetic studies. Can. J. Neurol. Sci. 20(Suppl. 4):83.

Carroll. P.. SendtNer. M.. Meyer, M.. and THOENEN, H. (1993). Rat ciliary neurotrophic factor (CNTE): Gene structure and regulation of $\mathrm{m} R \mathrm{NA}$ in glial cell cultures. Glia 9:176-187.

Ciatterbuck. R. E., Price. D. L.. and Koliatsos. V. E. (1993). Ciliary neurotrophic factor prevents retrograde neuronal death in the adult central nervous system. Proc. Nat! Acat. Sci. USA 90:2222-2226.

Collins, F. (1984). An effect of nerve growth factor on the parasympathetic ciliary ganglion. I. Neurosci. 4:1281-1288.

CURTIS, R., AdRYAN, K. M., ZHU, Y., HARKNESS, P. J., LINDSAY, R. M., and DISTEFANO, P. S. (1993). Retrograde axonal transport of ciliary neurotrophic factor is increased by peripheral nerve injury. Nature $365: 253-$ 255.

Davis, S., Aldrich, T. H., VAlenzuela, D. M., WONG, V.. FURTH. M. E. SQUINTO. S. P.. and YANCopoulos, G. D. (1991). The receptor for ciliary neurotrophic factor. Science 253:59-63.

Davis, S., AldRici, T. H., STAHL, N., PAN, L., TAGA, T., Kishimoto, T., IP, N. Y.. and YANCOPOULOS. G. D. (1993a). LIFR $\beta$ and gp 130 as heterodimerizing. signal transducers of the tripartite CNTF receptor. Science 260: 1805-1808.

Distefano, P. S., Curtis, R., Panayotató, N., GaSCAN, H. CHEVAlIER. S., and YanCOPOUlOS. G. D. ( [993b). Released form of CNTF receptor-alpha component as a soluble mediator of CNTF responses. Science 259:1736-1739.

De Vos, A. M. ULtSCH. M.. and KossiakofF, A. A. (1992). Human growth hormone and extracellular domain of its receptor: crystal structure of the complex. Science 255:306-312.

DitTrich. F.. Thoenen. H. and Sendiner, M. ( [994). Ciliary neurotrophic factor: pharmacokinetics and acute phase response. Ann. Neurol. 35:151163.

Dobrea, G. M., UNNERSTALl, J. R.. and RaO, M. S. (1992). The expression of CNTF message and immunoreactivity in the central and peripheral nervous system of the rat. Dev. Brain Res. 66:209-219.

Ebendal. T. Belew, M.. JACOBSON, C.-O.. and PorATH, J. (1979). Neurite outgrowth elicited by embryonic chick heart: partial purification of the active factor. Neturosci. Lett. 14:91-95.

Ebendal. T., Olson. L.. Seiger. A.. and Hedlund, K.-O. (1980). Nerve growth factor in the rat iris. $\mathrm{Na}$ ture 286:25-28.

ERNSBERGER, U., SENDTNER. M., and ROHRER, H. (1989). Proliferation and differentiation of embryonic chick sympathetic neurons: effects of ciliary neurotrophic factor. Neuron. 2:1275-1284.

Friedman, B., Scherer, S. S., Rudge, J. S., Helgren, M., Morrisey, D., MCClain. J., WANG. XX. WIEGAND. S. J.. FURTH. M. E.. LINDSAY. R. M. and IP.
N. Y. (1992). Regulation of ciliary neurotrophic factor expression in myelin-related schwann cells in vivo. Neuron 9:295-305.

Gearing, D. P., Ziegler, S. F., Comeau, M. R.. Friend, D. ThOMA, B. COSMan, D., PARK, L, and Mosley, B. (1994). Proliferative responses and binding properties of hematopoietic cells transfected with low-affinity receptors for leukemia inhibitory factor, oncostatin M, and ciliary neurotrophic factor Proc. Natl Acad Sci. USA 91:1119-1123.

GiovanninI, M., Romo, A. J., and Evans, G. A. (1993). Chromosomal localization of the human ciliary neurotrophic factor gene (CNTF) to $1 \mathrm{lq} 12$ by fluorescence in situ hybridization. Cytogenet. Cell Genet. 63:62-63.

HAGG, T., Quon, D., HigAKJ, J., and VARON. S. (1992). Ciliary neurotrophic factor prevents neuronal degeneration and promotes low affinity NGF receptor expression in the adult rat CNS. Neuron 8:145-158.

HAGG, T, and VARON, S. ( 1993a). Ciliary neurotrophic factor prevents degeneration of adult rat substantia nigra dopaminergic neurons in vivo. Proc. Natl Acad. Sci. USA 90:6315-6319.

HAGG. T., VARON, S., and LouIS, J.-C. (1993b). Ciliary. neurotrophic factor (CNTF) promotes low-affinity nerve growth factor receptor and CD4 expression by rat CNS microglia. J. Neuroimmunol. 48:177-188.

HATTEN, M. E., LYNCH, M., RYDEL, R. E., SANCHEZ, J., Joseph, S. J., Moscatell, D., and RIFKIND, D. B. (1988). In vitro neurite extension by granule neurons is dependent upon astroglial-derived fibroblast growth factor. Dev: Biol. 125:280-289.

Helfand, S. L., SMITH, G. A., and Wessells, N. K. (1976). Survival and development in culture of dissociated parasympathetic neurons from ciliary ganglia. Dev, Biol. 50:541-547.

Helgren, M. E., Friedman. B., Kennedy, M., MullHOLLAND, K, MESSER, A., WONG, VBB., and LINDSAY, R. M. (1992). Ciliary neurotrophic factor (CNTF) delays motor impairments in the mud mouse, a genetic model of motor neuron disease. Netrosci. Abstr. 267.11:618. (Abstract)

Helgren, M. E.. Squinto. S. P.. Davis. H. L.. Parry, D. J., BOULTON, T. G., HeCK, C. S., ZHU, Y., YANCOPOULOS, G. D., LINDSAY, R. M., and DISTEFANO. P. S. (1994). Trophic effect of ciliary neurotrophic factor on denervated skeletal muscle. Cell 76:493-504.

Henderson, J. T. Seniuk, N. A., and Roder, J. C. (1994). Localization of CNTF immunoreactivity to neurons and astroglia in the CNS. Mot. Brain Res. 22:151-165.

Hill, M. A. and Bennett. M. R. (1983). Cholinergic growth factor from skeletal muscle elevated following denervation. Neurosci. Lett. 35:31-35.

Hooisma, J., SlaAf, D. W., MeEter, E., and Stevens. W. F. (1975). The innervation of chick striated muscle fibers by the chick ciliary ganglion in tissue culture. Brain Res. 85:79-85. 
Huber, J., Dittrich, F.. and Phelan, P. (1993). Characterisation of high-affinity and Jow-affinity receptors for ciliary neurotrophic factor. Eur. $J$ Biochem. 218:1031-1039.

Hughes. R. A., Sendtner, M., and Thoenen, $H$. (1993). Members of several gene families influence survival of pat motoneurons in vitro and in vivo. $J$. Neurosci. Res. 36:663-671.

Hughes. S. M. LiLlien. L. E. RAFF. M. C.. RoHRER, H., and SENDTNER. M. (1988). Ciliary neurotrophic factor induces type-2 astrocyte differentiation in culture. Nature 335:70-73.

IP, N. Y., LI, Y., VAN DE STADT, I., PANAYOTATOS, N.. ALDERSON. R. F.. and LINDSAY, R. M. (1991), Ciliary. neurotrophic factor enhances neuronal survival in embryonic rat hippocampal cultures. I. Neurosci. 11:3124-3134.

IP, N. Y. and Yancopoulos, G. D. (1992). Ciliary neurotrophic factor and its receptor complex. Prog. Growth Factor Res 4:139-155.

IP, N. Y, MCClain, J , BARREZUETA, N. X., ALDRICH, T. H., PAN, L.. Ll. Y., WIEGAND, S.. FRIEDMAN. B.. Davis, S., and Yancopoulos, G. D. (1993a). The a-component of the CNTF receptor is required for signaling and defined potential CNTF targets in the adult and during development. Neuron 10:98-102.

IP. N. Y.. WIEGAND. S. J.. MORSE. J.. and RUdGE, J. S. (1993b). Injury-induced regulation of ciliary neurotrophic factor messenger-RNA in the adult-rat brain. Eur. J. Netroset: 5:25-33.

JESSEN, K. R. and MIRSKY, R. (1992). Schwann cells: early lineage, regulation of proliferation and control of myelin formation. Curreni Opinion Neurobial. 2:575581.

KAllestad, J. C., Shoxab, M. and Linsley, P. S. (1991). Disulfide bond assignment and identification of regions required for functional activity of oncostatin M. J. Biol. Chem. 266:8940-8945.

KaUPMANN, K., SENDTNER, M., StÖCKu, K. A., and JoCKUSCH, H. (1991). The gene for ciliary neurotrophic factor (CNTF) maps to murine chromosome 19 and its expression is not affected in the hereditary motoneuron disease 'wobbler' of the mouse. Eur. J. Neturosei, 3;1 182-1186.

KRÜTTGEN, A., ROSE-JOHN, S., DUfHUES, G., BENDER, S., LUTTTICKEN, C., FREYER, P., and HEINRICH, P. C. (1990a). The three carboxy-terminal amino acids of human interleukin-6 are essential for its biological activity. FEBS Lett. 273:95-98.

KRÜTtGen, A., ROSE-JoHn, S., MÖller, C., Wroblowski, B., WOllmer. A., Múllberg, J., Hirano. T., Kishimoto, T., and HeINRICH, P. C. (1990b). Structure-function analysis of human interleukin-6: Evidence for the involvement of the carboxy-terminus in function. FEBS Leth. 262:323-326.

La Spada, A. R., Wilson, E. M., Lubahn, D. B., HardING, A. E., and FISCHBECK, K H. (199L). Androgen receptorgene mutations in X-linked spinal and bulbar muscular atrophy. Nature 352:77-79.

LaM, A., Fuller, F., Mililer, J., Kloss, J, MaNTHORPE. M., VARON, S., and CORDELL, B. (1991). Sequence and structural organization of the human gene encoding ciliary neurotrophic factor. Gene 102:27 I276.

LANDMESSER, L. and PILAR, G. ( 1974 ). Synapse formation during embryogenesis on ganglion cells lacking a periphery. $J$ : Physiol (London) 241:715-736.

LAVAlL, M. M., UNOKI, K, Y ASUMURA, D., MATTHES, M. T., YANCOPOULOS, G. D., and SteinberG, R. H. ( 1992 ). Multiple growth factors. cytokines. and neurotrophins rescue photoreceptors from the damaging effects of constant light. Proc Nall. Acad. Sci. USA 89: 1 1249- 11253

Le Douarn, N. M. and Terllet, M.-A. (1974). Experimental analysis of the migration and differentiation of neuroblasts of the autonomic nervous system and of neuroectodermal mesenchymal derivatives using a biological cell marking technique. Dev. Biol. 41:162-184.

LEUNG D. W. PARENT. A. S. CACHANES G. ESCH. F.. Coulombe, J. N., Nikolics, K., ECKenstein, F. P., and NiSH, R. (1992). Cloning, expression during development and evidence for release of a trophic factor for ciliary ganglion neurons. Neuron 8:1045-1053.

LIEBL, D. J. and Koo. P. H. (1993). Comparative binding of neurotrophins (NT-3, CNTF and NGF) and various cytokines to $\alpha 2$-macroglobulin. Biochem. Biophys Res. Commum 193:1255-1261.

Lillien. L. E.. Sendtner. M. RoHrer. H. Hughes. S. M., and RaFF, M. C. (1988). Type-2 astrocyte development in rat brain eultures is initiated by a CNTFlike Protein produced by Type-1 astrocytes. Neuron 1:485-494.

Lillien, L. E., Sendtner, M., and Raff, M. C. (1990). Extracellular matrix-associated molecules collaborate with ciliary neurotrophic factor to induce type-2 astrocyte development, $J$. Cell Biol. 112:635-642.

LiN. L.-F., Mismer, D. LILE, J. D., ARMES. L. G.. BUTLER, III, E. T., VANNICE, J. L. and Collins, F. (1989). Purification, cloning, and expression of ciliary neurotrophic factor (CNTF). Science 246:10231025 .

LiN, L.-F. H., Armes, L. G., Sommer, A., Smith, D. J., and Collins. F (1990). Isolation and characterization of ciliary neurotrophic factor from rabbit sciatic nerves. J. Biol. Chem 265:8942-8947.

LONGO, F. M., MANTHORPE, $M$, and VARON, $S$. (1982). Spinal cord neurotrophic factors (SCNTFs):I Bioassay of Schwannoma and other conditioned media. Dev. Brain Res. 3:277-294.

LoUji, J. C.: MAGal, E., BURNHAM, P., and VARON, S. (1993a). Cooperative effects of ciliary neurotrophic factor and notepinephrine on tyrosine-hydroxilase expression in cultured rat locus-ceruleus neurons. Dev. Biol. 155:1-13. 
LOUIS, J.-C., MAGal, E., TAKAYAMa, S., and VARON, S. (1993b). CNTF protection of oligodendrocytes against natural and tumor necrosis-factor-induced death. Seience 259:689-692.

Lütticken, C., KRUttgen, A., Moller, C., Heinrich, P. C., and Rose-JoHN, S. (1991). Evidence for the importance of a positive charge and an $\alpha$-helical structure of the $C$-terminus for biological activity of human IL-6. FEBS Lett. 282:265-267.

Magal, E., Burnham. P., and VARON, S. (1991). Effects of ciliary neuronotrophic factor on rat spinal cord neurons in vitro: survival and expression of choline acetyltransferase and low-alfinity nerve growth factor receptors, Dev. Brain Res. 63:141-150.

MAGAL, E., BURNHAM, P., VARON, S., and LOUIS, J. C. (1993a). Convergent regulation by ciliary neurotrophic factor and dopamine of tyrosine-hydroxylase expression in cultures of rat substantia-nigra. Netmoscience 52:867-881.

MAGAL, Ex LOUS, J.-C.. OUDEGA, M., and VARON, S. (1993b). CNTF promotes the survival of neonatal rat corticospinal neurons in vitro. NeuroRepom 4:779782.

Manthorpe, M., Skaper, S. D., Barbin, G., and VARON, S. (1982). Cholinergic neuronotrophic factors. Concurrent activities on certain nerve growth factor-responsive neurons. $J$. Neurochem. 38:415421 .

Manthorpe, M., Skaper, S. D., Williams, L. R, and VARON, S. (1986). Purification of adult ral sciatic nerve ciliary neuronotrophic factor. Brain Res. $367: 282-286$.

MANTHORPE. M. and VARON. S. (1985). Regulation of neuronal survival and neuritic growth in the avian ciliary ganglion by trophic factors. In: Growth and MatuFaton Factors. G. Guroff, eds John Wiley \& Sons. New York, 77-117.

MartinOU. J. C.. MARTiNOU. I.. and Kato. A. (1992). Cholinergic differentiation factor (CDF/LIF) promotes survival of isolated rat embryonic motoneurons in vitro. Neuren $8: 737-744$

MARWTTT, R., PILAR, G., and WEAKLY, J. N. ( 197.1 ). Characterization of two ganglion cell populations in avian ciliary ganglia. Brain Res. 25:317-334.

MASIAKOWSKI, P., LIU, H., RADZIEJEWSK, C., LOTTSPEICH, F., OBERTHUER, W., WONG. V.. LINDSAY. R. M. Furth, M. E., and Panayotatos, N. (199 I ), Recombinant human and rat ciliary neurotrophic factors. J. Neurochem 57:1003-1012.

Masu, Y., Wolf, E., Holtmann, B., Sendtner, M., BREM, G., and THOENEN, H. (1993). Disruption of the CNTF gene results in motor neuron degeneration. Nature 365:27-32,

McManaman, J. L.. CRawford. F. G. Stewart. S. S. and APPEL, S. H. (1988), Purification of a skeletal muscle polypeptide which stimulates choline acetyl- transferase activity in cultured spinal cord neurons. $J$. Biol. Chem. 263:5890-5897.

Momanaman, J. L., Oppenheim. R. W.. PRevette, D., and MARCHETTI. D, (1990). Rescue of motoneurons from cell death by a purified skeletal muscle polypeptide: effects of the ChAT development factor. CDF. Neuron 4:891-898.

MCMLlaN, M. K.. ThaI, L., HONG, J.-S., O'CALLAGHAN, J. P, and PENNYPACKER, K. R. (1994). Brain injury in a dish: a model for reactive gliosis. Trends Neurosci 17:138-142.

Meyer, M., MATSUOKA, I.. WetMore, C. OLSON, L. and THOENEN, H. (1992). Enhanced synthesis of brain-derived neurotrophic factor in the lesioned peripheral nerve: different mechanisms are responsible for the regulation of BDNF and NGF $m R N A, I$. Cell Biol. 119:45-54.

METCALF, D. and Gearing, D. P. ( 1989). Fatal syndrome in mice engrafted with cells producing high levels of the leukemia inhibitory factor. Proc. Natl. Acad. SCi. USA 86:5948-5952.

MitTSUMOTO. H. IKEDA. K., WONG, V., LindSAY, R. M. and CEDARBAum, J. M. (1992). Recombinant human ciliary neurotrophic factor (rHCNTF) improves muscle strength in wobbler mouse motor neuron disease. Genetics and Cell Biolngy of the Motor neume Third Internationat Symposium on ALS/ MND. T6. (Abstract)

NARAYANAN, C. H. and NARAYANAN. Y. (1978). Neuronal adjustments in developing nuclear centers of the chick embryo following transplantation of an additional optic primordium. J. Embryol. Exp. Morphol. 44:53-70.

Negro, A.. Corona, G., Bigon, E., Martini, i. Grandi, C, Skaper, S. D, and Callegaro, L. (1991). Synthesis. purification, and characterization of human ciliary neuronotrophic factor from $E_{\text {. coli }}$. J. Neurosci. Res. 29:251-260.

Negro, A., Corsa, V., CORONA, G., Grandi, C. SKAPER, S. D. and CALLEGARO L, (1994). Structure-function studies of human ciliary neurotrophic factor. Neurochem. Res. 19:223-227.

Nesbitt, J. E., Fuentes, N. L. and Fuller, G. M. (1993). Ciliary neurotrophic factor regulates fibrinogen gene expression in hepatocytes by binding to the interleukin-6 receptor. Biochem. Biophys. Res. Commun 190:544-550.

NISH, R. and BERG, D. K. (1977). Dissociated ciliary ganglion neurons in vitro: survival and synapse formation. Proc. Natl. Acad. Sci. USA 74:5171-5175.

NisHa, R. and BERG, D. K. (1979). Survival and development of ciliary ganglion neurones grown alone in cell culture. Nature 277:232-234.

NiSHI, R. and BERG. D. K. (1981). Two components from eye tissue that differentially stimulate the growth and development of ciliary ganglion neurons in cell culture. J. Neturosci 1:505-513. 
O'CONNOR, T. M. and WYTTENBACH, C. R. (1974). Cell death of the embryonic ehick spinal cord. $J$. Cell Biol. 60:448-459.

OPPENHEIM. R. W. (1986). The absence of significant postnatal motoneuron death in the brachial and lumbar spinal cord of the rat. I. Comp. Neurol 246:281286.

Oppenheim, R. W., Prevette, D., Qin-Wei, Y., CoiLINS. F. and MACDONALD, J. (1991), Control of embryonic motoneuron survival in vivo by ciliary neurotrophic factor. Science 251:16!16-1618.

Panayotatos, N., RadzIEJEWSKa, E., ACHESON, A., PeARSALl, D., ThadANi, A., and Wong, V. (1993). Exchange of a single amino acid interconverts the specific activity and gel mobility of human and rat ciliary neurotrophic factors. if. Biol. Chem. 268:1900019003.

PAtterson, P. H. (1992). The emerging neuropoietic cytokine family: first CDF / LIF, CNTF and IL-6; next ONC, MGF, GCSF? Current Opinion Neurobiol: 2:94-97.

PILAR, G. and LANDMESSER, L. ( 1976). Ultrastructural differences during embryonic cell death in normal and peripherally deprived ciliary ganglia. J. Cell Biol. 68:339-356.

Pllar, G.; LANDMEsSER, L., and Burstein, L. ( 1980 ). Competition for survival among developing ciliary. ganglion cells. $J$. Netrophysiol. 43:233-253.

RAO. M. S. TYRRELL. S.. LANDIS, S. C. and PATTERSON, P. H. (1992). Effects of ciliary neurotrophic factor (CNTF) and depolarization on neuropeptide expression in cultured sympathetic neurons. Dev. Biol. 150:281-293

Rende. M., Muir, D., Rouslathl, E., HagG, T., VARON, S, and MANTHORPE, M. ( 1992 ). Immunolocalization of ciliary neuronotrophic factor in adult rat sciatic nerve. Glia 5:25-32,

RichaRdSON. P. M. and EBENDAL. T. (1982). Nerve growth factor activities in rat peripheral nerve. Brain Res. $246: 57-64$.

Rosen, D. R., Siddique, T., Patterson. D., FigleWiCz. D. A. SAPp، P.. Hentati. A., Donaldson, D., Goto, J., OREgan, J. P., Deng, H.-X., RaHMaN, Z.; KRIZUS, A., MCKENNA-YASEK, D., CAYABYAB, A., Gaston. S. M., Berger. R., TANZI. R. E.. HALPERIN, J. J., HERZFELDT, B., VAN DEN BERG, R., Hung, W.-Y. BIRD, T., DENG, G., MULder, D. W. SMYth. C. LaIng, N. G.. Soriano, E., PertcakVANCE, M. A., HaInes, J., ROUleau, G. A., GuSELLA, J. S., HoRvitZ, H. R., and BROWN, JR., R. H. (1993). Mutation in $\mathrm{Cu} / \mathrm{Zn}$ superoxide dismutase gene are associated with familial amyotrophic lateral sclerosis. Nature 362:59-62.

Rudge, J. S., Alderson, R. F., PASNIKOWSKI, E.. MCCLAIN. J.. IP. N, Y.. and LINDSAY, R. M. (1992). Expression of ciliary neurotrophic factor and the neurotrophins - nerve growth factor, brain-derived neuro- trophic factor and neurotrophin 3 in cultured rat hippocampal astrocytes. Eur. J. Neurosct 4:459-471.

RUdGE, J. S., MORRISSEY, D., LINDSAY, R. M., and PASNIKOWSKI, E. M. (1994). Regulation of ciliary neurotrophic factor in cultured rat hippocampal astrocytes. Eur. J. Neurosei 6:218-229.

SAADAT, S., SENDTNER, M., and RoHRER, H. (1989). Ciliary neurotrophic factor induces cholinergic differentiation of rat sympathetic neurons in culture. $J$. Cell Biol. 108:1807-1816.

SCHOOLTINK. H. Stoyan, T. RoEB. E., HEINRICH. P. C.. and Rose-JoHN, S. (1992). Ciliary neurotrophie factor induces acute-phase protein expression in hepatocytes. FEBS Lett. 314:280-284.

SENDTNER, M.* ARAKAWA. Y.. STÖCKLI, K. A. KreutZBERG, G. W., and THOENEN, H. ( 1991). Effect of ciliary neurotrophic factor (CNTF) on motoneuron survival. J. Cell Sci. Sippl. 15:103-109.

Sendtner, M., Kreutzberg, G. W., and Thoenen, H. (1990). Ciliary neurotrophic factor prevents the degeneration of motor neurons after axotomy. Nature 345:440-441.

SENDTNER, M. STÖCKLI, K. A., and THOENEN, H. (1992a). Synthesis and Iocation of ciliary neurotrophic factor in the rat sciatic nerve of the adult rat after lesion and during regeneration. I: Cell Biol. 118:139148.

SENDTNER. M.. SCHMAlbRUCH. H.. StÖCKLI. K. A. Carroll, P., Kreutzberg, G. W , and Thoenen, H. (1992b). Ciliary neurotrophic factor prevents degeneration of motor neurons in mouse mutant progressive motor neuronopathy. Nature 358:502-504.

SENDTNER, M., STöCKLi, K. A., CARROLL, P., KREUTZBerG, G. W., ThOENEN, H., and SCHMALbRUCH, $H$. (1992c). More on motor neurons. Nature 360:54 I542 .

SENIUK, N., ALTARES, M., DUNN, R., and RICHARDSON, P. M. (1992). Decreased synthesis of ciliary neurotrophic factor in degenerating peripheral nerves. Brain Res. 572:300-302.

Sentuk, N. A., Henderson, I. T., Tatton, W. G., and RODER. J.C. (1994). Increased CNTF gene expression in process-bearing astrocytes following injury is augmented by $\mathrm{R}(-)$-deprenyl. I. Neurosci. Res. 37:278-286.

SHAPRO, L., ZHANG, X.-X, RuPP, R, G., WOLFF, S. M., and DINARELLO, C. A. (1993). Ciliary neurotrophic factor is an endogenous pyrogen. Proc Natl. Acad. Sci. USA 90:8614-8618

SKaper, S. D., Negro, A., Dal Toso, R., and FACCl, L, (1992). Recombinant human ciliary neurotrophic factor alters the threshold of hippocampal pyramidal neuron sensitivity to excitotoxin damage: synergistie effects of monosialogangliosides. $J$. Neurosci. Res. 33:330-337.

Stöckli. K. A.. LotTSPEICH. F., Sendtner. M.. MASIAKOWSKI, P., CARROLL, P., GÖTZ, R., LINDHOLM, D., and THOENEN, H. (1989). Molecular cloning, ex- 
pression and regional distribution of rat ciliary neurotrophic factor. Nature 342:920-923.

StÖCKLI, K. A., LILlieN, L. E., NÄHER-NoE, M., BrettFeld, G., Hughes, R. A., Thoenen, H., and SENDTNER, M. (1991). Regional distribution, developmental changes and cellular localization of CNTFRNA and protein in the rat brain. J. Cell Biol. 115:447-459.

TAGA, T. and Kishimoto, T. (1992). Cytokine receptors and signal transduction. FASEB J. 6:3387-3396.

ThOBNEN, H. (1991). The changing scene of neurotrophic factors. Trends Neurosci. 14:165-170.

Thoenen, H., Hughes, R. A., and Sendtner, M. (1993). Trophic support of motoneurons: physiological, pathophysiological, and therapeutic implications. Exp. Neurol. 124:47-55.

UNSICKER, K., REICHERT-PREIBSCH, H., SCHMIDT, R., Pettmann. B., Labourdette, G., and SensenbrenNER, M. ( 1987). Astroglial and fibroblast growth factors have neurotrophic functions for cultured peripheral and central nervous system neurons. Proc. Natl. Acad. Sci. USA, 84:5459-5463.

WALLACE, T. L. and JOHNSON EM, J. R. ( 1987 ). Partial purification of a parasympathetic neurotrophic factor in pig lung. Brain Res. 411:351-363.

WATters. D. J. and HendRY, I. A. (1987), Purification of a ciliary neurotrophic factor from bovine heart. $J$. Neurochem. 49:705-7!3.

Wessells, N. K., NutTall, R. P.. WReEM, J. T., and JOHNSON, S. (1976). Differential labelling of the cell surface of single ciliary ganglion neurons in vitro. Proc: Nall. Acad. Sci. USA 73:4100-4104.

WILliams, L. R., MANTHORPE, M.. BARBIN. G., NiETOSAMPEDRO, M., COTMAN. C. W., and VARON. S. (1984). High ciliary neuronotrophic specific activity in rat peripheral nerve. Int. J. Dev. Neurosci. 2:177180.

WONG, V.. ARRIGA, R., IP, N., and LINDSAY, R. M. (1993). The neurotrophins BDNF, NT-3 and NT-4/ 5 , but not NGF, upregulate the cholinergic phenotype of developing motoneurons. Eur. J. Neurosci. 5:466474.

WOODWARD, W. R.. NISHI, R., MESHUL, C. K., WILliams. T. E. Coulombe, M., and Eckenstein, F. P. (1992). Nuclear and cytoplasmic localization of basic fibroblast growth factor in astrocytes and CA2 hippocampal neurons. J. Nelrosci. 12:142-152.

YAMAMORI, T., FukAda, K.. AEBersold, R.. KORSCHING, S., FANN, M. J., and PATTERSON, P. H. ( 1989 ). The cholinergic neuronal differentiation factor from heart cells is identical to leukemia inhibitory factor. Science 246:1412-1416. 